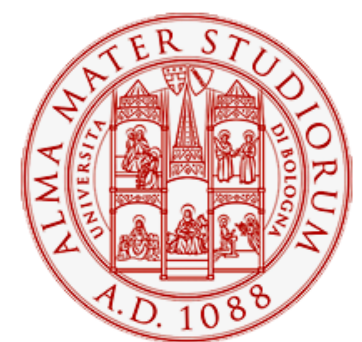

Alma Mater Studiorum - Università di Bologna DEPARTMENT OF ECONOMICS

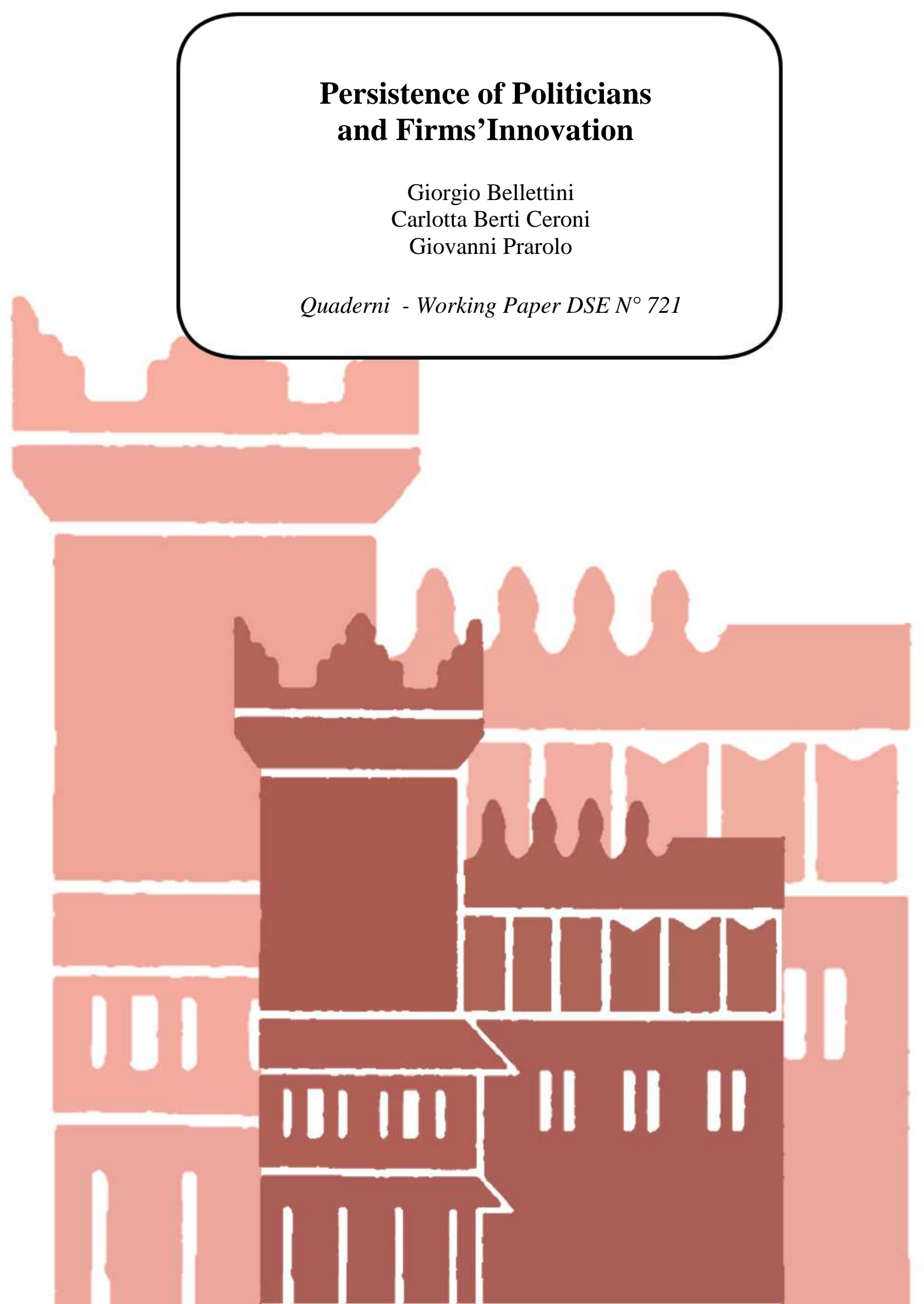




\title{
Persistence of Politicians and Firms' Innovation*
}

\author{
Giorgio Bellettini \\ University of Bologna, CHILD and CESifo \\ Carlotta Berti Ceroni \\ Giovanni Prarolo ${ }^{\dagger}$ \\ University of Bologna and CHILD \\ University of Bologna
}

November 2010

\begin{abstract}
We empirically investigate whether the persistence of politicians in political institutions affects the innovation activity of firms. We use 12,000 firm-level observations from three waves of the Italian Observatory over Small and Medium Enterprises, and introduce a measure of political persistence defined as the average length of individual political careers in political institutions of Italian municipalities. Standard OLS shows no raw correlation between political persistence and firms' innovation activity. However, once the causal effect is isolated by means of instrumental variables, using death of politicians as an exogenous source of variation of political persistence, we find a robust negative relation between political persistence and the probability of process innovation. This finding is consistent with the view that political stability may hinder firms' incentive to innovate to maintain their competitiveness, as long as they can extract rents from long-term connections with politicians.
\end{abstract}

JEL Classification: D22, D72, O31

Keywords: innovation, politicians, tenure, instrumental variable

${ }^{*}$ We would like to thank Chiara Monfardini, Marcello Morciano, Martin Rossi and Giulio Zanella for helpful suggestions. We benefited from comments and discussions with participants at seminars at Bologna and the XV DEGIT Conference in Frankfurt. All remaining errors are ours alone.

${ }^{\dagger}$ Corresponding author. Email: giovanni.prarolo@unibo.it. Department of Economics, University of Bologna, P.zza Scaravilli 2, 40126 Bologna, Italy. 


\section{Introduction}

In many circumstances, the coexistence of long-lived economic and political elites is blamed for countries' low rate of technological innovation and economic growth. Through longlasting personal relations, contacts and acquaintances ("knowing the right person in the right place"), the sociopolitical network between politicians and economic actors tends to create a stable elite that rules the country, preventing the access to power by more dynamic individuals. Although a (possibly negative) relationship between perpetuation of political and economic power and innovation is often mentioned in policy debates, neither a wellestablished economic theory nor convincing empirical evidence are available to support this view.

To formally address these issues, in this paper we empirically investigate whether the Italian local political environment, in particular the persistence of the same persons in the local political institutions, affects private firms' propensity to innovate. By concentrating on a single country, we avoid concerns emerging when countries with very different institutional settings are put together in cross-country analysis. Yet, information on Italian politicians is available at the local level, including municipality level, thus potentially providing substantial spatial variation in measures of persistence of politicians. Moreover, the insufficient replacement of power elite is often considered to be among the causes of Italy's economic decline. As Carboni [8] puts it, "Italy is falling behind and the unconcern of our elites about our future is probably the consequence of the obsolescence of the country and of our circles of power ruled by a gerontocratic core" (page 6, our translation).

We first construct a measure of political persistence in Italian municipalities, where persistence is defined as the average longevity in office of individuals appointed in local political institutions over a given period, from 1985 to 2007, the longest time span available, or a sub-period. Our measure of persistence considers the pool of politicians of a municipality as the entity with which firms interact, rather than focusing on the individual connection between a firm and a politician, as it the case in the literature about the impact of political connections on firms' economic performance (see for instance Faccio [15]). Being based on individual data on political careers, our measure also differs significantly from proxies for political stability that have been previously used in the literature (see for example Alesina et al. [1]). We then merge these political data with socioeconomic data that include, among others, relevant information on the location and innovation activity of Italian small and medium enterprises for a total of about 12.000 observations in the period 1998-2006. 
Using this detailed dataset, we perform a cross-sectional analysis where the probability of process innovation is related to political persistence in the municipality where the firm is located. Due to the spurious correlation between our two main variables, we estimate the model by instrumental variables, using the unexpected death of politicians in a municipality as a source of exogenous variation in political persistence.

The main result of our empirical analysis is that, when we consider process innovation, the innovation activity of firms located in a municipality is negatively affected by the average length in office of local politicians. More specifically, our instrumental variables estimates suggest that a six months increase in politicians' average longevity lowers the probability of process innovation by $15 \%$, including province fixed effects and other controls at the municipality and firm level. Moreover, we find that older firms are more affected by political persistence than younger ones, and that the impact of political persistence is slightly stronger for firms that operate in industries heavily dependent on the public sector. Finally, when product innovation is considered rather than process innovation, the negative effect of political persistence vanishes.

In principle, political longevity has ambiguous effects on innovation. On the one hand, a stable political environment may reduce uncertainty regarding future policy choices thereby increasing the expected return from long-term investment and innovation. On the other hand, by exploiting long-term connections with politicians, firms may enjoy preferential treatment in terms of lower burden of administrative costs, easier access to credit and production factors (e.g. public utilities) and public procurement. ${ }^{1}$ These advantages may generate rents for incumbent firms, reducing their incentive to innovate to upgrade technologies and increase productivity in order to maintain their competitive position.

Our empirical findings, which support a negative impact of political persistence on the probability of process innovation are consistent with the latter view. In a related theoretical paper (see Bellettini, Berti Ceroni and Prarolo [3]) we put forward a possible explanation for such negative relationship, whereby entrepreneurs might choose to invest in time-consuming political connections, aimed at curbing bureaucratic costs, rather than spend resources to innovate. In this framework, political persistence makes investment in political connections profitable for firms and reduces the incentive to innovate.

Our paper is related to various strands of literature. First, it belongs to the literature on the external determinants of firms' innovation activity, where the external determinant

\footnotetext{
${ }^{1}$ There is evidence that managers spend a sizable fraction of their working time in meeting with politicians. Boeri et al. [5], using a survey on Italian CEOs, find that the fraction of working time they spend with politicians $(7 \%)$ is comparable with the time spent in dealing with banks.
} 
we take into consideration is individual persistence in local political institutions. Many contributions in this literature focus, instead, on the availability of credit, showing that a well functioning, competitive banking system and the physical proximity of banks positively affect firms' innovation activity (see, among others, Bonaccorsi di Patti and Gobbi [6], King and Levine [19] and Guiso et al. [18]). In particular, our empirical approach borrows from the one developed by Benfratello et al. [4] who, using previous waves of the same data on Italian firms, investigate the effect of local banking development, measured by the number of bank branches per capita in a province, on firms' innovation activity. Beside focusing on a completely different external determinant (political persistence rather than financial development), which involves the development of a new instrument specific to our key explanatory variable, we have a finer spatial definition of the local environment, at municipality, rather than province level. This allows us to control for province-specific fixed effects (which may also capture banking development at province level) when we investigate the effect of our main explanatory variable.

Second, from a macroeconomic perspective, a large theoretical and empirical literature, surveyed in Carmignani [9], suggests a positive link between governments' term length (political stability) and economic growth, as instability and the threat of changes in the legislative environment make firms less willing to invest. Most of these studies rely on measures of political instability based on revolutions, coups and assassinations, or the frequency of government turnover, which are very different from ours, based on individual data on the length of political careers.

Third, some contributions have used measures of political persistence similar to ours to investigate different issues. Coviello and Gagliarducci [12] show that mayors' longevity in office in Italian municipalities negatively affects the efficiency of public procurement, as the number of bidders of an auction and the winning rebate decrease, while the probability that the winning firm is an insider and that the contract is ex-post renegotiated increase with longevity. Using cross-country data, Campante et al. [10] investigate the relationship between corruption and political stability, measured as the average tenure of chief executives and governing parties over a given period. Their empirical findings show that corruption tends to increase with stability in relatively stable environments, as the prospect of long-term deals with the politicians raises firms' willingness to involve in bribing and rent-seeking activities.

Finally, a growing literature studies the effect of political connections on firms' performance. Using Italian data, Cingano and Pinotti [13] look at the private returns and social costs of politically connected firms matching data on Italian firms' employees and politi- 
cians. Defining a firm as connected if a politician is among its employees, they quantify the gain from political connection in a $5 \%$ increase in revenues, obtained through changes in domestic sales and not through exports or productivity enhancements. Using international data, Faccio [15] and Faccio et al. [16] highlight that whenever firms are owned or managed by politicians (or their friends and relatives), their market value increases and they are significantly more likely to be bailed out than similar non-connected firms. ${ }^{2}$ Desai and Olofsgard [14] investigate the consequences of political connections on about 10.000 firms surveyed in 40 developing countries and find that influential firms face fewer administrative and regulatory burdens and invest and innovate less.

The rest of the paper is organized as follows. Section 2 describes the data and Section 3 presents our empirical strategy and estimation results. Section 4 concludes.

\section{Data}

To construct our dataset we use two main sources of information, the historical archive of local administrators of the Italian Ministry of Internal Affairs and waves eight, nine and ten of the Observatory over Small and Medium Enterprises, that have been produced by Capitalia (the first two) and UniCredit. Other data come from the Italian Institute of Statistics (ISTAT)

\subsection{Municipality-level data}

Our source of information for political variables is the historical archive of local administrators of the Italian Ministry of Internal Affairs. This archive records yearly, between 1985 and 2007, and for each municipality (8095 in 2007), data on mayors (sindaci), councilmen (consiglieri) and members of the executive committee (assessori).

The mayor and councilmen are elected and the mayor appoints the members of the executive committee (giunta). ${ }^{3}$ In municipalities with less than 15000 inhabitants $(90 \%$ of the total) members of the executive committee can be chosen among councilmen, while the two roles are incompatible in municipalities with more than 15000 inhabitants. Both the giunta, i.e. the executive power, and the council, i.e. the legislative power, play a role

\footnotetext{
${ }^{2}$ The unexpected death of politicians has been used as a source of exogenous changes in political connections of firms by Faccio and Parsley [17] and Roberts [22]. Our instrumental variable strategy is inspired by these contributions.

${ }^{3}$ Electoral rules concerning the election of the mayor were changed in 1993. The mayor was appointed by the winning party or coalition before, while he has been directly elected by citizens afterwards. Elections took place every five years for most of the time span under analysis.
} 
in setting and enforcing regulation that may affect firms' activities. According to Law Decree n.267/2000, which collects laws ruling local administrations, their tasks include the concession of public utilities, setting the rules of agreements for private provision of public goods, designing the rules to which public utilities have to comply, organizing and supervising tenders, ruling and deciding upon building permits, among others.

For each politician, we have information regarding name, surname, date of birth, position held (sindaco/consigliere/assessore and role within the institution), dates of election, appointment and resignation. The cause of resignation is also available. Using these data, we build measures of political persistence $P E R S_{Y 1-Y 2}$ for each municipality, where $P E R S_{Y 1-Y 2}$ is defined as the average number of years spent within local political institutions by politicians of a municipality in the period $Y 1-Y 2$. More specifically, for each individual (uniquely defined by his name, surname and birth date) we sum the length of appointments served in the given period within a municipality and then take the average over all individuals that served in that municipality. Taking politicians' longevity in office as a measure of influence on municipality's economic life, here we are possibly identifying a lower bound. In fact, although politicians exit the sample once they are appointed at province, regione or country level, their influence on local issues may be even higher. Moreover, before or after being appointed in political institutions, individuals may be employed as bureaucrats in municipal apparatuses, or in firms owned or controlled by the municipality, where connections with the productive sector are also possible.

Descriptive statistics for PERS $1985-2007$ and PERS $1985-2000$ are collected in Table $1 .^{4}$ The variable $P E R S_{1985-2007}$ exploits all available information, as it considers the longest time span covered by the data. In the empirical analysis, however, our main variable of interest will be $P E R S_{1985-2000}$, which has the advantage of being largely predetermined with respect to firm-specific variables. We also calculate $P E R S_{1994-2007}$, as 1993 represents an important breaking point in Italian politics. ${ }^{5}$ The number of municipalities for which data are available is 7652 , as we exclude municipalities that disappeared merging

\footnotetext{
${ }^{4}$ Statistics for $P E R S_{1994-2007}$ are not reported as this variable turns out to be very highly correlated

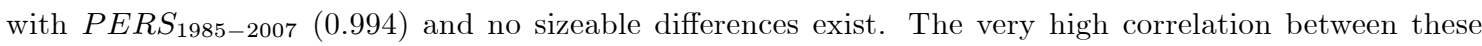
two variables could be driven by lack of information on politicians in the first years of data. As long as the under-report of politicians is random, there are no issues of distortion in the estimates.

${ }^{5}$ As already noted, electoral rules changed in 1993. Moreover, following a series of inquisitions conducted in 1992 and 1993 (generally referred to as "Mani Pulite") and scandals that uncovered a widespread system of corruption between entrepreneurs and politicians at all institutional levels ("Tangentopoli"), the political parties that had been previously ruling Italian politics collapsed, leading to the end of the so called "First Republic". The variable PERS $S_{1994-2007}$ allows us to avoid the use of data pre-Mani Pulite.
} 
with other municipalities during the 1985-2007 period and those with key information missing.

In the full sample, the mean and median value of PERS $S_{1985-2007}$ are both around five years and three months, with a standard deviation of one year. As $P E R S_{1985-2007}$ is the average length in office of politicians in each municipality, these numbers indicate a non-negligible variance across municipalities. PER $S_{1985-2007}$ is higher in municipalities with population smaller that 15000 inhabitants, as expected due to the aforementioned law, lower in capital cities of provinces and regions (this is likely to be a size effect since capital cities are on average larger than other municipalities), and higher in the North. ${ }^{6}$

The last two rows of Table 1 report descriptive statistics once the sample is split in two sub-samples, according to whether at least one politician aged 60 or less died in a municipality in the period 1990-2005 (DEATH=1) or not (DEATH=0). As we will explain later, we will use death of a relatively young politician as a source of exogenous variation of political persistence. The difference between the mean values of $P E R S_{1985-2007}$ in the two sub-samples is around three months and is statistically significant, with municipalities where at least one death occurred showing lower mean. Table 1 also reports statistics for PERS $1985-2000$, which is generally higher than $P E R S_{1985-2007}$, indicating a decline in the length of political careers in recent years. As before the mean value is lower in municipalities where at least one death event occurred in the 1990-2005 period.

Table 2 reports descriptive statistics for other municipalities' variables that will be used in the empirical analysis, namely labor force participation rate $(L F P R)$, population $(P O P)$, the elderly index, i.e. the share of inhabitants aged 65 or more $\left(E L D \_I N D E X\right)$, and the share of foreigners $\left(S H_{-} F O R\right)$. Data for these variables come from the 2001 Census. As a proxy for local human capital (TERT_EDU), we take the share of workers with tertiary education measured within Local Systems of Labor (these are 686 entities that group contiguous municipalities according to commuting patterns of workers). ${ }^{7}$

Table 3 reports pairwise correlations. As expected, $P E R S_{1985-2007}$ and $P E R S_{1985-2000}$ are (weakly) negatively correlated with population and with the binary variable $D E A T H$. Notice that DEATH is positively correlated with population, as a larger population of politicians implies a larger probability of having at least one death event.

\footnotetext{
${ }^{6}$ A visual inspection of Figure 1 shows that $P E R S_{1985-2007}$, besides being higher in the North, is also higher at higher altitudes, as in the Alps and Appennines.

${ }^{7}$ A detailed list of variables is available in the Appendix.
} 


\section{$2.2 \quad$ Firm-level data}

The firm-level information we use come from waves eight, nine and ten of the Observatory over Small and Medium Enterprises. The surveys, conducted in 2001, 2004, and 2007 on a sample of Italian manufacturing firms, provide information on innovation activities for the previous three-year periods (1998-2000, 2001-2003, and 2004-2006). In each wave the sample is selected (partly) with a stratified method for firms with up to 500 workers, whereas firms above this threshold are all included. Each survey contains, respectively, 4680, 4289 and 5137 manufacturing firms and some of them are interviewed more than once (in particular 2480 are interviewed twice and 451 three times).

Around four in ten firms introduced process innovation $\left(I N N_{-} P R O C\right)$, which will be our main dependent variable. In our view, process innovation is a better proxy for the cost-saving and/or productivity enhancements of firms, which may be influenced by connections with local politicians. Instead, product innovation is more likely to be linked to demand-pull factors, such as the demand for new goods associated with exports (see Becker and Egger [2] for a discussion). In the empirical analysis, we will also use data on other firms' characteristics from the same surveys, such as the total number of employees $\left(O C C_{-} T O T\right)$ and the share employed in $\mathrm{R} \& \mathrm{D}\left(\mathrm{SH}_{-} \mathrm{OO}_{-} \mathrm{RD}\right)$, turnover (TURNOVER), age of the firm (AGE), whether the firm is an exporter $\left(D_{-} E X P O R T\right)$, a corporation $\left(S O C \_C A P\right)$, belongs to a business group $(G R O U P)$, made use of temporary workers $(E X T E R N A L)$, and is controlled by a person $\left(M A I N_{-} C O N T R_{-} P E R S\right)$, and industry of activity.

\subsection{The dataset}

The dataset that we will use to perform our empirical analysis was obtained by merging municipalities' data with firms' data, according to the municipality where a firm is located. ${ }^{8}$ We trimmed the sample at the first and last percentiles of turnover, innovation expenditure, number of employees and PERS $S_{1985-2007}$ to exclude outliers. We also excluded firms not operating in manufacturing, together with those located in municipalities that experienced at least one period of special administration. ${ }^{9}$

\footnotetext{
${ }^{8}$ Some concerns may arise about the endogenous strategic location of firms. However, we believe that firms' locations are not primarily driven by the municipality-level determinants that we are mainly interested in, and in particular by political persistence. Michelacci and Silva [20] report that roughly $80 \%$ of Italian entrepreneurs locate their firms in the same province where they were born.

${ }^{9}$ Under special administration, a non-elected administrator is appointed by the central government until new elections take place. This may happen because of resignation of the mayor, mafia infiltrations,
} 
Between one fourth and one third of Italian municipalities host at least one firm interviewed in the surveys (see Figure 2), with 2353 municipalities represented in the dataset. On average there are five firms for each municipality, but firms' distribution is not homogeneous. Around $27 \%$ of the municipalities host only one firm, the median value is three firms, $25 \%$ of the municipalities host more than five firms, and four municipalities (Rome, Prato, Turin and Milan) host 975 firms together. Average population of the municipalities in the dataset is around 15500, which is larger than the average in the full sample (7200), confirming that firms tend to settle in larger municipalities.

Descriptive statistics for our dataset are collected in Table 4. Process innovation takes place in $41 \%$ of the observations. The average age of firms is 28 , the vast majority of them $(94 \%)$ is a corporation, and the entity controlling the firm is a person in $71 \%$ of the cases. In the lower panel of the Table, we report some descriptive statistics for municipalities' variables in the dataset. Capital cities, which are larger than average, are over-represented in the sample: more than $21 \%(10 \%)$ of the firms are located in provincial (regional) capital cities. Over-representation of firms in capital cities explains why the mean value of PERS $S_{1985-2007}$ is smaller in the dataset (4.82) than it was in the full sample (5.25). Again, PER $S_{1985-2000}$ has higher mean value (5.56) than PER $S_{1985-2007}$. Finally, death of a relatively young politician in the period 1990-2005 occurred in $31 \%$ of the observations.

Pairwise correlations (Table 5) show that process innovation is positively correlated with firm size (measured in terms of log of turnover and log of employees), with the status of exporter and with the share of employees in R\&D. ${ }^{10} P E R S_{1985-2007}$ is positively correlated with process innovation and the status of exporter, although the correlation coefficients are very low, and PERS $1985-2000$ is weakly correlated with the status of exporter. The correlation between PERS $1985-2007$ and PERS $S_{1985-2000}$ is 0.85 and significant at $1 \%$. $D E A T H$ is not correlated with process innovation and weakly correlated with exporter status. Instead, it is negatively correlated with PER $S_{1985-2007}$ and $P E R S_{1985-2000}$.

\section{Empirical analysis}

Our goal in this section is to investigate whether political persistence in the political institutions of a municipality affects the innovation activity of firms. As the dependent variable $I N N_{-} P R O C$ is binary, we estimate a linear probability model with political persistence as explanatory variable. The analysis is cross-sectional, with observations

municipality going bankrupt, etc.

${ }^{10}$ This is consistent with findings by Costantini and Melitz [11], among others. 
for the three waves pooled together, given the intrinsically time-invariant nature of our measures of persistence. Our key explanatory variable will be $P E R S_{1985-2000}$, which has the advantage of being largely predetermined with respect to innovation activity between 1998 and 2006.

Before proceeding, let us discuss whether a simple linear regression of innovation activity on local political persistence would deliver reliable results in terms of causality. Clearly, many other factors, external or internal to the firm, play a role in determining firms' propensity to innovate, and will be considered in our analysis. However, our main concern is the likely presence of unobservables that could simultaneously affect firms' innovation propensity and the local political environment, and in particular the selection and election of politicians. For example, weak or poorly enforced institutions may lead to adverse selection of politicians within a restricted pool of candidates, and negatively affect the selection process of firms, allowing the diffusion of malpractice in the relation between politicians and firms, with widespread corruption and preferential treatment of incumbents.

Moreover, reverse causality could bias our results downwards. Low performance in terms of innovation activity by firms in a municipality could be perceived by the electorate as the consequence of mismanagement of local policies and poor choices regarding, for example, the maintenance and development of infrastructure, the quality of the bureaucracy, the efficiency of public utilities provision, inducing voters to replace the ruling political elite. ${ }^{11}$

In order to tackle endogeneity and omitted variables issues, we will estimate the model by 2 SLS. The proposed instrument is a dummy variable taking value one (zero) if at least one (no) politician aged 60 or less died in a municipality in the considered period. Although we can not directly test for exogeneity of the instrument, death of at least one politician appointed in a municipality should impact on process innovation only through political persistence. Whether the instrument is relevant is an empirical issue. The effect on political persistence of death of a politician may be negligible if he/she is replaced by someone already serving in another role (as it may be more likely in municipalities with less than 15000 inhabitants) or who was in office before. Thus, we tried several first stage regressions using dummies for death events calculated over different time intervals and selected as instrument death calculated over the 1995-2000 period, which turned out to

\footnotetext{
${ }^{11}$ The idea that economic outcomes may affect electoral outcomes can be traced back to theoretical contributions by Rogoff and Sibert [24], Rogoff [23] and Persson and Tabellini [21], among others. According to Brender and Drazen [7], such effects are not so clearly supported by empirical evidence, however.
} 
be significantly associated with our measures of political persistence. ${ }^{12}$

The general specification of our model is the following:

$$
I N N_{-} P R O C_{i}=\alpha_{1} \mathbf{X}_{i}+\alpha_{2} P E R S_{1985-2000 i}+\varepsilon_{i}
$$

with first stage:

$$
P E R S_{1985-2000 i}=\beta_{1} \mathbf{X}_{i}+\beta_{2} D E A T H_{1995-2000 i}+\eta_{i}
$$

where $i$ indicates firms, $\mathbf{X}_{i}$ is a vector that, depending on specifications, includes region (20 regions) and province (103 provinces) dummies, to capture determinants of innovation activity related to institutional characteristics which are common across municipalities belonging to such entities (including, for example, banking development in the province of residence, which has been found to positively affect firms' process innovation by Benfratello et al. [4]), dummies for the sector of activity (23 sectors), and wave dummies.

In some specifications, we include further proxies that control for the local environment at municipality level, such as the elderly index, the share of foreigners, labor force participation rate, the share of workers with tertiary education, altitude, a polynomial in $P O P$ to take into account population-related effects ${ }^{13}$, a set of dummies for population size, $P O P<3 K, 3 K<P O P<10 K, 10 K<P O P<30 K, 30 K<P O P<100 K$, $100 K<P O P<250 K, 250 K<P O P<1 M, P O P>1 M$, chosen to match the discontinuous changes in the number of councilmen occurring at these thresholds as ruled by law, a dummy taking value one (zero) for municipalities with more (less) than 15000 inhabitants, and dummies indicating the semesters in which elections took place. ${ }^{14}$

Among firms' characteristics, we consider the (log) number of employees, (log) turnover, the share of workers employed in $\mathrm{R} \& \mathrm{D}$, age, dummies indicating whether the firm declares to be a corporation, to be part of a business group, to be controlled by a person, to be an exporter, and whether it made use of temporary workers. We also use dummies indicating whether the firm operates in a high tech-sector or in a sector strongly dependent on public demand. For the latter two variables, our classification follows Benfratello et al [4] and Cingano and Pinotti [13], respectively. ${ }^{15}$

\footnotetext{
${ }^{12}$ In particular, death calculated over the 1990-1995 (1990-1995 or 2000-2005) period was not significantly associated with $P E R S_{1985-2000}\left(P E R S_{1985-2007}\right)$ in the first stage. Also, death calculated over the longer 1990-2000 (1990-2005) period was not significantly associated with $P E R S_{1985-2000}\left(P E R S_{1985-2007}\right)$.

${ }^{13}$ Population may also proxy for the level of development as data for GDP at municipality level are not avilable.

${ }^{14}$ As expected, these population-related controls turn out ot to be highly significant in the first stage. As firms' decisions, for example regarding location, are not exogenous to municipality size, they could not be used as excluded instruments.

${ }^{15} \mathrm{~A}$ detailed list of variables and their definition is provided in the Appendix.
} 


\subsection{Estimation results}

Table 6 reports the estimated coefficient for our key explanatory variables obtained under different specifications of the model. In all cases, reported standard errors are robust to heteroskedasticity. We also provide estimation results (in parenthesis) obtained by clustering standard errors at municipality level, the dimension along which political persistence varies.

We first estimate (1) by OLS, including among regressors only region, wave and semester dummies, together with a dummy indicating whether the municipality is a capital city. As shown in column (1), this estimation delivers a coefficient of PER $S_{1985-2000}$ that is not significantly different from zero. Column (2) reports results obtained by probit estimation of the same specification which yields the same point estimate (and standard errors) for the coefficient of PERS $S_{1985-2000}$. In column 3, the model is estimated by 2SLS using $D E A T H_{1995-2000}$ as instrument for $P E R S_{1985-2000}$. In the first stage $D E A T H_{1995-2000}$ is strongly negatively correlated with $P E R S_{1985-2000}$, with the Staiger-Stock's rule of thumb of $F>10$, indicating non-weak instruments, being largely satisfied. ${ }^{16}$ The point estimate of $D E A T H_{1995-2000}$ suggests that the death of (at least) one politician aged 60 or less lowers average length in office of politicians in a municipality by roughly two months, after controlling for region, semester, wave, and capital city fixed effects. In the second stage the coefficient of PERS $1985-2000$ is negative and significant at $5 \%$ level (10\% if standard errors are clustered at municipality level). The point estimate suggests that a one standard deviation increase in $P E R S_{1985-2000}$ implies a reduction in the probability of innovation by $20 \% .^{17}$

In column 4, we add municipality controls, the polynomial of population, and population dummies. The coefficient of $P E R S_{1985-2000}$ is unchanged. Among municipality controls, only the share of workers with tertiary education has positive effect on innovation (at $1 \%$ level), with an estimated coefficient of 0.2755 [s.e. 0.1020]. Other controls are not

\footnotetext{
${ }^{16}$ Given the firm-level nature of our analysis and that DEATH $H_{1995-2000}$ and $P E R S_{1985-2000}$ are both municipality-level variables, this correlation may be due to the presence of many observations for which the association between the two variables is negative. In order to check whether the strenght of our instrument captures a true statistical association, we regress PER $S_{1985-2000}$ on the same controls used in column 3, employing the full sample with municipality-level data rather than the dataset with firm-level observations. Estimation by robust OLS delivers a coefficient for DEATH $H_{1995-2000}$ equal to -0.1578 (significant at $1 \%$ level), confirming the validity of our instrument.

${ }^{17}$ A simple 2SLS regression of $I N N_{-} P R O C$ on $P E R S_{1985-2000}$ and a constant (with first stage only including $D E A T H_{1995-2000}$ and a constant) already delivers a negative and significant at $10 \%$ level coefficient for PERS $1985-2000$ (point estimate -0.0279).
} 
significant at conventional levels.

In column 5, we replace region with province dummies, and start to add proxies of firms' characteristics. We first include firms' characteristics that are less likely to be endogenous to innovation activity, such as the log number of employees, age, dummies indicating whether the firm is controlled by a person, belongs to a business group, is a corporation, and dummies indicating whether the firm operates in a high-tech sector or in a sector strongly dependent on public demand. The coefficient of $P E R S_{1985-2000}$ is very similar and still significant at $5 \%$ level. Controls that turn out to be significant at $1 \%$ level are the log number of employees, with estimated coefficient 0.0831 (s.e. 0.0057), and the public demand dummy, with estimated coefficient 0.0415 (s.e. 0.0101). The high-tech dummy is significant at $5 \%$ level, with estimated coefficient 0.0250 (s.e. 0.0111). The log number of employees takes into account scale effects at firm level, while the positive coefficient associated to the public demand dummy is likely to be due to the fact that the highly innovative chemical sector is also a sector highly dependent on public demand. Finally, in column 6 we add all other firm-level controls, in particular (the log of) turnover, the share of labor force in $R \& D$, dummies indicating use of temporary workers and the status of exporter, and sector dummies. The estimated coefficient of $P E R S_{1985-2000}$ is again unchanged. ${ }^{18}$

In Table 7 we report results obtained using alternative measures of political persistence and instruments as robustness checks, taking the model's specifications that include municipality variables (column 4, Table 6) and some firms' characteristics (column 5, Table 6) as benchmarks. In columns 1 and 2, the measure of persistence is $P E R S_{1985-2007}$. Results are similar to those obtained using $P E R S_{1985-2000}$, both in the first and in the second stage. When we try $P E R S_{1994-2007}$, political persistence is still negative and significant at $5 \%$ confidence level in the second stage, as shown in columns 3 and 4 . Next, we replicate the estimate including municipality and firm-level variables (as in column 5, Table 6), using $P E R S_{1985-2000,} P E R S_{1985-2007}$ and $P E R S_{1994-2007}$ (one at a time) as measures of persistence and instrumenting them with the alternative variable $N D E A T H_{1995-2000}$, that is the number of politicians aged 60 or less dead in a municipality divided by the average number of politicians in office in the 1995-2000 period. ${ }^{19}$ Even if more accurate in

\footnotetext{
${ }^{18}$ In this specification the estimated effect of the share of labor force in R\&D is positive and highly significant, while the coefficient of the high-tech dummy becomes negative. This may be due to the positive correlation between these variables.

${ }^{19}$ When $D E A T H_{1995-2000}$ is used, even if we control for the size of municipalities by including population dummies and the population polynomial, we attribute the same average effect of a death event on political persistence in municipalities with different numbers of politicians. Instead, when $N D E A T H_{1995-2000}$ is
} 
principle, this instrument delivers weaker first stage estimates, with a sizable reduction of the F-statistics in two out of three cases. Moreover, the estimated coefficients of political persistence are still negative but no longer significant in the second stage. The most stable results are obtained with $P E R S_{1985-2000}$, our main measure of persistence: although not significant at conventional level, the estimated coefficient of political persistence is negative ( $14 \%$ confidence level) in the second stage and the F-statistic remains large in the first stage.

\subsection{Differential responses to political persistence and alternative depen- dent variables}

We believe that our results so far provide robust evidence that local political persistence determines a negative impact on firms' innovation activities leading to productivity improvements, after controlling for fixed institutional features at region and province level, the economic environment at the municipality level, and firms' characteristics. The effect is sizable, as our point estimates indicate that an increase in average political longevity in the municipality by one standard deviation reduces the probability of process innovation by $20-30 \%$ (depending on the measure of political persistence). In particular, according to estimates obtained in our preferred specification (column 5, Table 6), a six months increase in average political longevity reduces the probability that a firm located in the municipality innovates by $15 \%$. As discussed in the Introduction, this finding is consistent with a negative effect of political stability on firms' propensity to invest in innovation to increase productivity. This may be due to the fact that, by exploiting political connections with stable politicians, firms may reduce the incidence of bureaucratic and administrative costs and remain competitive even if they do not upgrade their technologies (see Bellettini, Berti Ceroni and Prarolo [3] for a theoretical model developing this view) or may obtain preferential treatment in public procurement or other activities controlled by local politicians.

In order to further investigate the relationship between political persistence and innovation activity, we consider alternative specifications of our model. First, we allow for the possibility of differential effects of political persistence on process innovation, depending on firms' characteristics, such as age and sector of activity, that may determine the importance of stability of the political elite for the firm. For example, older firms may

used, the number of death events is normalized by the number of politicians in each municipality, so that the coefficient in the first stage represents the change of persistence (in number of years) if all the politicians had to die contemporaneously, under the assumption that tenure is the same for all politicians. 
have established stronger connections with politicians and therefore be more affected by political persistence than younger firms. Also, the value of political connections and the effect of political persistence may be higher for firms operating in industries highly dependent on the public sector. Next, we consider alternative dependent variables, such as product innovation, firms' turnover and size. Product innovation may be mainly determined by demand-driven external factors unaffected by the local environment and the average longevity in office of politicians. Instead, the latter may influence profitability and therefore measures of firms' performance, such as turnover and size.

We start by testing for differential responses to political persistence by including interaction terms in the model's specification with municipality and firm-level variables (Column 5, Table 6). We investigate first the effect of firms' age by introducing two interaction terms where $P E R S_{1985-2000}$ is multiplied by two dummy variables, taking value one when the firm is younger or older than 15 years, respectively. In the first stage, the interactions of $D E A T H_{1995-2000}$ with the two dummies are used as instruments. ${ }^{20}$ As shown in column 1, Table 8, the estimated coefficient of $P E R S_{1985-2000}$ for young firms is not different from zero, while for old firms it is negative and significant at $5 \%$ confidence level. ${ }^{21}$ First stage estimates, not reported for brevity, do not indicate problems related to weak instruments. Next, we focus on differential responses of firms belonging or not to industries classified as mainly serving the public sector. As before, we introduce two interaction terms where $P E R S_{1985-2000}$ is multiplied by two dummies indicating whether the firm operates in an industry highly dependent on the public sector or it does not, respectively, and use interactions of $D E A T H_{1995-2000}$ with the two dummies as instruments. It turns out that the impact of $P E R S_{1985-2000}$ on innovation activity is slightly larger for firms operating in industries highly dependent on the public sector. ${ }^{22}$ As we found before, the public dummy variable is positive and significant (at 10\% level), with an estimated coefficient of 0.3422 (s.e. 0.1946). Again, first stage estimates are not reported for brevity.

Columns 3 and 4 , Table 8 , report results obtained considering alternative dependent variables. When we use product innovation $\left(I N N_{-} P R O D\right)$, rather than process innovation, as dependent variable, the probability to innovate is not affected by $P E R S_{1985-2000}$ (column 3). ${ }^{23}$ Instead, turnover $\left(L O G \_T U R N\right)$ is positively affected by political persis-

\footnotetext{
${ }^{20}$ See Wooldridge [25], Chapter 6, for details.

${ }^{21}$ The Wald test for different coefficients is not significant at conventional level: the confidence level is only $16 \%$.

${ }^{22}$ The Wald test for different coefficients is significant only at $12 \%$ confidence level.

${ }^{23}$ In their study of the effect of local banking development on firms' innovative activities, Benfratello
} 
tence, which is significant at $10 \%$ level (column 4). Occupation ( $L O G \_O C C$ ), another measure of firm size, is not significantly related to $P E R S_{1985-2000}$ (column 5).

Overall, these results suggest that the negative influence of political persistence on the probability of process innovation is more important in older firms and (even if slightly) in firms operating in industries that mainly serve the public sector, where political connections are likely to be stronger and more widespread. Moreover, political persistence, which negatively affects the probability of process innovation, has no effects on product innovation, and positive effect (if any) on firms' market performance. Although they are based on a completely different approach, these findings can be considered complementary to those of Cingano and Pinotti [13], who provide evidence that political connections, measured by the presence of local politicians among employees, grant Italian firms a premium in terms of revenues, which is not related to improvements in productivity, and is driven by firms operating in sectors that most intensively provide inputs to the public administrations.

\section{Conclusion}

The political and economic environment in which a firm operates is crucial in shaping its innovation activity. In this paper we investigate whether longevity in office of administrators appointed in local political institutions affects the probability of process innovation of firms.

Our analysis is based on a rich dataset where survey-based information on Italian firms in the 1996-2008 period are merged with data on administrators serving in local political institutions between 1985 and 2007. Starting from information on individual political careers, we constructed measures of political persistence, defined as the average longevity in office of politicians in a municipality in a given period. These measures were included among explanatory variables of the probability of process innovation of firms located in the municipality. To isolate the causal effect of political persistence on innovation, we estimate a linear probability model by 2SLS, using death of relatively young politicians as a source of exogenous variation of political persistence.

Our estimates support a sizable negative effect of political persistence on the probability of process innovation which is robust to the inclusion of firm and municipality-level controls and several dummies, including province and region fixed effects. There is also some evidence that the negative impact of political persistence on innovation is stronger

et al. [4] find that the evidence of such effect is weaker when product innovation, rather than process innovation, is considered. 
in older firms and firms operating in industries that mainly serve the public sector, and that political persistence has positive effect on firms' market performance, as measured by turnover.

These findings are consistent with the view that political stability may reduce firms' incentive to increase productivity, possibly as it allows firms to establish and exploit connections with long-tenured politicians and to obtain preferential treatment in domains of economic activity controlled by local administrators.

\section{References}

[1] Alesina, A., Ozler, S., Roubini, N., and P. Swagel, (1996), "Political Instability and Economic Growth", Journal of Economic Growth, 1, 193-215.

[2] Becker, S.O., P.H. Egger (2010), "Endogenous Product Versus Process Innovation and Firm's Propensity to Export," Empirical Economics, forthcoming.

[3] Bellettini, G., C. Berti Ceroni, G. Prarolo (2009), "Knowing the Right Person in the Right Place: Political Connections and economic Growth," FEEM Working Paper 2009.107.

[4] Benfratello, L., F. Schiantarelli, A. Sembenelli (2008), "Banks and Innovation: Microeconometric Evidence on Italian Firms," Journal of Financial Economics, 90, 197-217.

[5] Boeri, T., A. Merlo, A. Prat (2010), La Classe Dirigente, Università Bocconi Editore, Milan.

[6] Bonaccorsi di Patti, E., G. Gobbi (2001), "The Changing Structure of Local Credit Markets: Are Small Businesses Special?," Journal of Banking and Finance, 25, 22092237 .

[7] Brender, A., A. Drazen (2008), "How Do Budget Deficits and Economic Growth Affect Reelection Prospects? Evidence from a Large Panel of Countries," American Economic Review, 98(5), 2203-20.

[8] Carboni, C. (2007), "Elite e classi dirigenti in Italia", Bari: Laterza.

[9] Carmignani, F. (2003), "Political Instability, Uncertainty and Economics", Journal of Economic Surveys, 17, 1-54. 
[10] Campante, F., Chor, D. and Q. Do (2008), "Instability and the Incentives for Corruption", Economics \& Politics, 21, 42-92.

[11] Costantini, J.A., M.J. Melitz (2008), "The Dynamics of Firm-Level Adjustment to Trade Liberalization." In: Helpman, E., D. Marin, T. Verdier (eds), The Organization of Firms in a Global Economy. Harvard University Press, Cambridge, MA.

[12] Coviello, D., S. Gagliarducci (2010), "Building Political Collusion: Evidence from Procurement Auctions," mimeo.

[13] Cingano, F., P. Pinotti. (2010), "Politicians at Work. The Private Returns and Social Costs of Political Connections", Bank of Italy Working Papers 709.

[14] Desai, R. M. and A. Olofsgard (2008), "Do Politically Connected Firms Undermine Their Own Competitiveness?" Brookings Global Economy and Development Working Paper, no. 18.

[15] Faccio, M. (2006), "Politically Connected Firms", American Economic Review, 96(1), 369-386.

[16] Faccio, M., J. J. McConnell, R. W. Masulis (2006), "Political Connections and Corporate Bailouts", Journal of Finance, 61(6), 2597-2635.

[17] Faccio, M., D.C. Parsley (2009), "Sudden Deaths: Taking Stock of Geographic Ties," Journal of Financial and Quantitative Analysis, 44(3), 683-718.

[18] Guiso, L., T. Jappelli, M. Padula, M. Pagano (2004), "Financial Market Integration and Economic Growth in the EU," Economic Policy, CEPR, CES, MSH, 19(40), 523-577.

[19] King, R., R. Levine (1993), "Finance, Entrepreneurship and Growth: Theory and Evidence," Journal of Monetary Economics, 32, 513-542.

[20] Michelacci, C., O. Silva (2007), "Why So Many Local Entrepreneurs?," The Review of Economics and Statistics, 89(4), 615-633.

[21] Persson, T., G. Tabellini (1990), Macroeconomic Policy, Credibility, and Politics, London: Harwood.

[22] Roberts, B. E. (1990), "A Dead Senator Tells No Lies: Seniority and the Distribution of Federal Benefits," American Journal of Political Science, 34, 31-58. 
[23] Rogoff, K. (1990), "Equilibrium Political Budget Cycles," American Economic Review, 80(1), 21-36.

[24] Rogoff, K., A. Sibert (1988), "Elections and Macroeconomic Policy Cycles," Review of Economic Studies 55(1), 1-16.

[25] Wooldridge, J. M. (2002), Econometric Analysis of Cross Section and Panel Data, MIT Press, Cambridge, MA.

\section{Appendix}

\begin{tabular}{|c|c|c|c|c|c|c|c|c|c|}
\hline & \multicolumn{4}{|c|}{ PERS $_{1985-2007}$} & \multicolumn{4}{|c|}{ PERS $_{1985-2000}$} & \multirow[b]{2}{*}{$\mathrm{N}}$. \\
\hline & Mean & St.Dev. & Min & $\operatorname{Max}$ & Mean & St.Dev. & Min & $\operatorname{Max}$ & \\
\hline Full Sample & 5.25 & 1.00 & 1.84 & 13.43 & 6.12 & 1.16 & 1.79 & 13.43 & 7652 \\
\hline Capital cities & 4.31 & 0.55 & 3.26 & 6.02 & 5.07 & 0.67 & 3.77 & 7.03 & 99 \\
\hline $\mathrm{POP}<15 \mathrm{~K}$ & 5.34 & 0.98 & 1.84 & 13.43 & 6.22 & 1.14 & 2.26 & 13.43 & 7004 \\
\hline $\mathrm{POP}>15 \mathrm{~K}$ & 4.29 & 0.75 & 1.99 & 6.62 & 5.01 & 0.86 & 1.79 & 7.66 & 648 \\
\hline North & 5.55 & 0.97 & 2.76 & 13.43 & 6.48 & 1.13 & 3.28 & 13.43 & 4295 \\
\hline Center-South & 4.87 & 0.92 & 1.85 & 8.83 & 5.65 & 1.04 & 1.03 & 10.19 & 3357 \\
\hline DEATH $=1$ & 4.99 & 0.95 & 2.32 & 9.32 & 5.79 & 1.12 & 2.84 & 10.32 & 886 \\
\hline $\mathrm{DEATH}=0$ & 5.29 & 1.00 & 1.84 & 13.43 & 6.16 & 1.16 & 1.79 & 13.43 & 6766 \\
\hline
\end{tabular}

Table 1. Descriptive statistics: PERS $S_{1985-2007}$ and PERS $S_{1985-2000}$

\begin{tabular}{|l|ccccc|}
\hline & Mean & St.Dev. & Min & Max & N. \\
\hline LFPR & 0.59 & 0.07 & 0.27 & 0.83 & 7652 \\
POP (X1000) & 7.24 & 40.41 & 0.033 & 2546.8 & 7652 \\
ELD_INDEX & 0.18 & 0.06 & 0.05 & 0.54 & 7652 \\
SH_FOR & 0.02 & 0.02 & 0.00 & 0.24 & 7652 \\
TERT_EDU & 0.18 & 0.06 & 0.08 & 0.64 & 7652 \\
\hline
\end{tabular}

Table 2. Descriptive statistics: municipalities' variables 


\begin{tabular}{l|ccccccc} 
& PERS $_{1985-2007}$ & PERS $_{1985-2000}$ & DEATH & LFPR & POP & ELD_INDEX & SH_FOR \\
\hline PERS $_{1985-2000}$ & $.897^{*}$ & & & & & & \\
DEATH & $-.077^{*}$ & $-.084^{*}$ & & & & & \\
LFPR & $.049^{*}$ & $.060^{*}$ & .021 & & & & \\
POP & $-.118^{*}$ & $-.130^{*}$ & $.075^{*}$ & $.027^{*}$ & & \\
ELD_INDEX & $.182^{*}$ & $.195^{*}$ & -.016 & $-.737^{*}$ & $-.068^{*}$ & & \\
SH_FOR & $.084^{*}$ & $.100^{*}$ & .018 & $.385^{*}$ & $-.024^{*}$ & $-.112^{*}$ & \\
TERT_EDU & $.071^{*}$ & $.066^{*}$ & $-.037^{*}$ & $-.029^{*}$ & $-.090^{*}$ & $.067^{*}$ & .013 \\
\hline
\end{tabular}

Table 3. Pairwise correlations: municipalities' variables. ${ }^{*}=1 \%$ significance. 


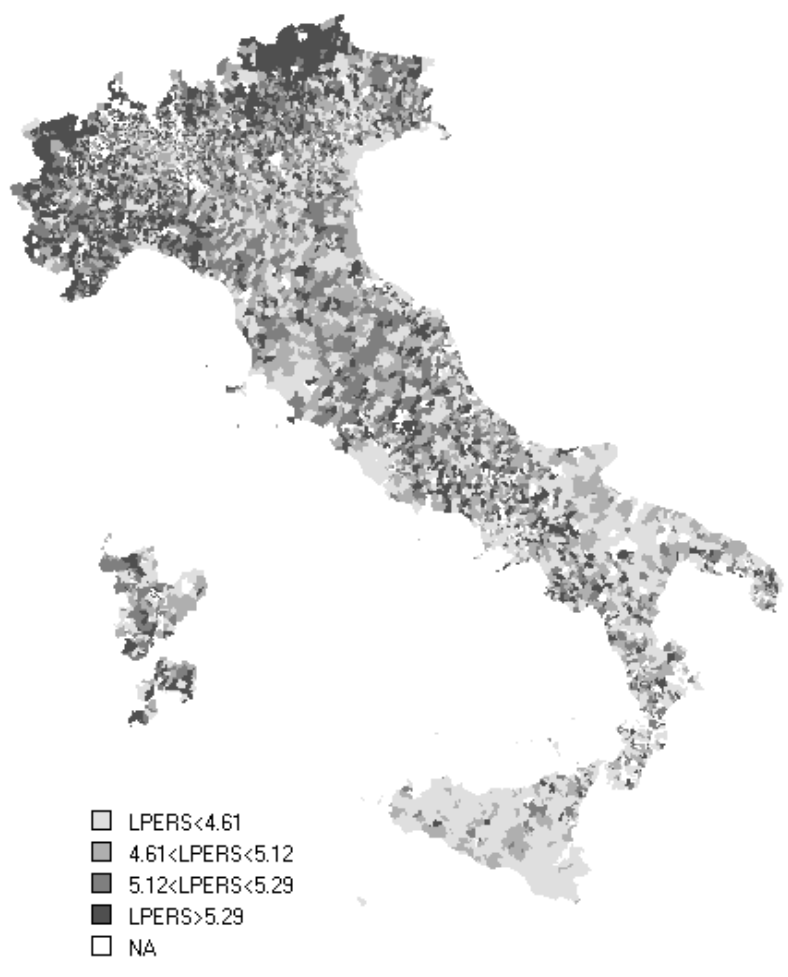

Figure 1. Spatial distribution: PERS $_{1985-2007}$ (LPERS in the map) 


\begin{tabular}{|c|c|c|c|c|c|}
\hline & Obs & Mean & St.Dev. & Min & Max \\
\hline INN_PROC & 12144 & 0.409 & 0.492 & 0 & 1 \\
\hline AGE & 11869 & 28.14 & 20.48 & 0 & 313 \\
\hline GROUP & 12144 & 0.231 & 0.421 & 0 & 1 \\
\hline $\mathrm{SOC}_{-} \mathrm{CAP}$ & 12144 & 0.942 & 0.234 & 0 & 1 \\
\hline EXTERNAL & 12144 & 0.432 & 0.496 & 0 & 1 \\
\hline MAIN_CONTR_PERSON & 12144 & 0.711 & 0.452 & 0 & 1 \\
\hline D_EXPORT & 12144 & 0.673 & 0.469 & 0 & 1 \\
\hline TURNOVER & 12066 & $16.8 \mathrm{M}$ & $3.96 \mathrm{M}$ & 0 & $850 \mathrm{M}$ \\
\hline $\mathrm{OCC}_{-} \mathrm{TOT}$ & 12144 & 76.6 & 136.99 & 4 & 1510 \\
\hline $\mathrm{SH}_{-} \mathrm{OCC}_{-} \mathrm{RD}$ & 11711 & 0.052 & 0.127 & 0 & 1 \\
\hline $\mathrm{CAP}_{-} \mathrm{REG}$ & 12144 & 0.109 & 0.312 & 0 & 1 \\
\hline $\mathrm{CAP}_{-} \mathrm{PROV}$ & 12144 & 0.215 & 0.411 & 0 & 1 \\
\hline TERT_EDU & 12144 & 0.156 & 0.058 & 0.077 & 0.535 \\
\hline ELD_INDEX & 12144 & 0.157 & 0.036 & 0.060 & 0.346 \\
\hline $\mathrm{SH}_{-} \mathrm{FOR}$ & 12144 & 0.039 & 0.022 & 0 & 0.185 \\
\hline LFPR & 12144 & 0.633 & 0.044 & 0.452 & 0.768 \\
\hline POP & 12144 & $139.7 \mathrm{~K}$ & $377.6 \mathrm{~K}$ & 339 & $2,546.8 \mathrm{~K}$ \\
\hline PERS $_{1985-2007}$ & 12144 & 4.820 & 0.681 & 2.756 & 6.785 \\
\hline PERS $_{1985-2000}$ & 12144 & 5.561 & 0.867 & 3.151 & 9.182 \\
\hline DEATH & 12144 & 0.311 & 0.463 & 0 & 1 \\
\hline
\end{tabular}

Table 4. Descriptive statistics for the dataset 


\begin{tabular}{|c|c|c|c|c|c|c|c|}
\hline & INN_PROC & $D_{-}$EXP & LOG_TURN & $\mathrm{LOG}_{-} \mathrm{OCC}$ & $\mathrm{SH}_{-} \mathrm{OCC}_{-} \mathrm{RD}$ & PERS $1985-2007$ & PERS $1985-2000$ \\
\hline$D_{-}$EXP & $.081^{*}$ & & & & & & \\
\hline LOG_TURN & $.137^{*}$ & $.271^{*}$ & & & & & \\
\hline $\mathrm{LOG}_{-} \mathrm{OCC}$ & $.164^{*}$ & $.267^{*}$ & $.797^{*}$ & & & & \\
\hline $\mathrm{SH}_{-} \mathrm{OCC}_{-} \mathrm{RD}$ & $.090^{*}$ & $.047^{*}$ & $.041^{*}$ & $.030^{*}$ & & & \\
\hline PERS $1985-2007$ & $.026^{*}$ & $.042^{*}$ & .000 & -.003 & .023 & & \\
\hline PERS $1985-2000$ & .018 & $.033^{*}$ & -.022 & -.030 & .022 & $.848^{*}$ & \\
\hline DEATH & -.007 & $.035^{*}$ & .004 & -.014 & .005 & $-.186^{*}$ & $-.254^{*}$ \\
\hline
\end{tabular}

Table 5. Pairwise correlations: selected variables. ${ }^{*}=1 \%$ significance. 


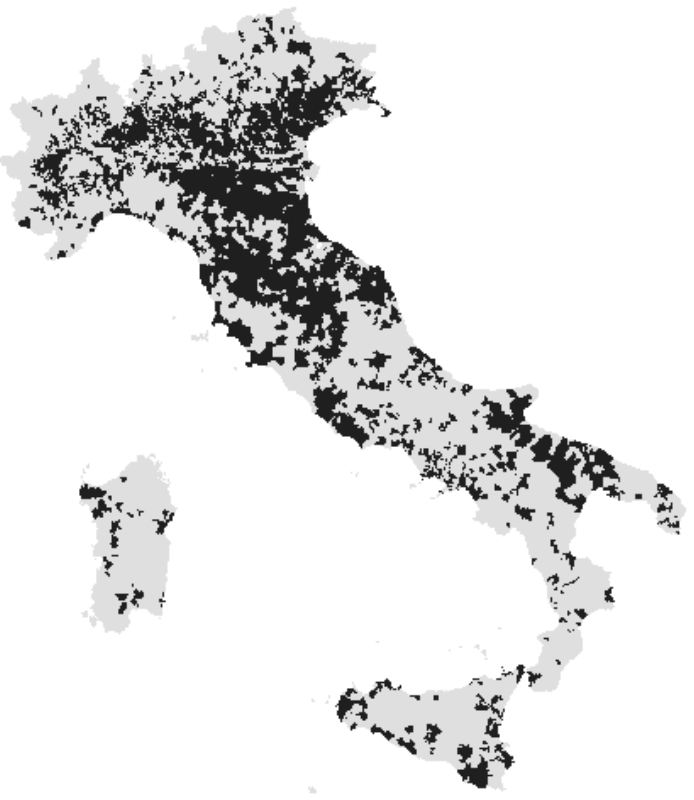

Figure 2. Municipalities hosting at least one firm (in dark) 


\begin{tabular}{|c|c|c|c|c|c|c|}
\hline & $(1)$ & $(2)$ & (3) & $(4)$ & $(5)$ & $(6)$ \\
\hline & OLS & Probit & IV & IV & IV & IV \\
\hline \multirow[t]{3}{*}{ PERS $_{1985-2000}$} & .0088 & .0088 & -.2449 & -.2436 & -.2593 & -.2509 \\
\hline & {$[.0084]$} & {$[.0084]$} & {$[.1107]^{* *}$} & {$[.1116]^{* *}$} & {$[.1254]^{* *}$} & {$[.1284]^{* *}$} \\
\hline & $(.0100)$ & $(.0100)$ & $(.1311)^{*}$ & $(.1311)^{*}$ & $(.1434)^{*}$ & $(.1450)^{*}$ \\
\hline MUNIC. CONTROLS & & & & $\mathrm{X}$ & $\mathrm{x}$ & $\mathrm{X}$ \\
\hline FIRM CONTROLS & & & & & SOME & FULL \\
\hline REGION & $\mathrm{X}$ & $\mathrm{X}$ & $\mathrm{X}$ & $\mathrm{X}$ & & \\
\hline PROVINCE & & & & & $\mathrm{X}$ & $\mathrm{X}$ \\
\hline SECTOR & & & & & & $\mathrm{X}$ \\
\hline WAVE & $\mathrm{X}$ & $\mathrm{X}$ & $\mathrm{X}$ & $\mathrm{X}$ & $\mathrm{X}$ & $\mathrm{X}$ \\
\hline CAPITAL CITY & $\mathrm{X}$ & $\mathrm{X}$ & $\mathrm{X}$ & $\mathrm{X}$ & $\mathrm{X}$ & $\mathrm{X}$ \\
\hline POP DUMMIES & & & & $\mathrm{X}$ & $\mathrm{X}$ & $\mathrm{X}$ \\
\hline POP POLINOMIAL & & & & $\mathrm{X}$ & $\mathrm{X}$ & $\mathrm{X}$ \\
\hline SEMESTER & $\mathrm{X}$ & $\mathrm{X}$ & $\mathrm{X}$ & $\mathrm{X}$ & $\mathrm{X}$ & $\mathrm{X}$ \\
\hline \multicolumn{7}{|l|}{$F I R S T S T A G E$} \\
\hline \multirow[t]{2}{*}{ DEATH $_{1995-2000}$} & & & -.1693 & -.1932 & -.1823 & -.1802 \\
\hline & & & {$[.0194]^{* * *}$} & {$[.0210]^{* * *}$} & {$[.0219]^{* * *}$} & {$[.0222]^{* * *}$} \\
\hline $\mathrm{F}$ & & & 76.04 & 84.82 & 69.56 & 65.93 \\
\hline Observations & 12144 & 12137 & 12144 & 12144 & 11869 & 11353 \\
\hline
\end{tabular}

Table 6. Results of OLS, Probit and IV estimation. Robust standard errors in brackets (clustered at municipality level in parentheses). 


\begin{tabular}{|c|c|c|c|c|c|c|c|}
\hline & (1) & $(2)$ & (3) & (4) & $(5)$ & (6) & (7) \\
\hline & IV & IV & IV & IV & IV & IV & IV \\
\hline \multirow[t]{2}{*}{ PERS $_{1985-2000}$} & & & & & -.2543 & & \\
\hline & & & & & {$[.1727]$} & & \\
\hline \multirow[t]{2}{*}{ PERS $1985-2007$} & -.3908 & -.4016 & & & & -.4599 & \\
\hline & {$[.1812]^{* *}$} & {$[.2002]^{* *}$} & & & & {$[.3332]$} & \\
\hline \multirow[t]{2}{*}{ PERS $1994-2007$} & & & -.3596 & -.3687 & & & -.4071 \\
\hline & & & {$[.1678]^{* *}$} & {$[.1815]^{* *}$} & & & {$[.2878]$} \\
\hline REGION & $\mathrm{X}$ & & $\mathrm{X}$ & & & & \\
\hline PROVINCE & & $\mathrm{X}$ & & $\mathrm{X}$ & $\mathrm{X}$ & $\mathrm{X}$ & $\mathrm{X}$ \\
\hline FIRM CONTROLS & & $\mathrm{X}$ & & $\mathrm{X}$ & $\mathrm{X}$ & $\mathrm{X}$ & $\mathrm{X}$ \\
\hline \multicolumn{8}{|l|}{ FIRST STAGE } \\
\hline \multirow[t]{2}{*}{ DEATH $_{1995-2000}$} & -.1204 & -.1177 & -.1309 & -.1283 & & & \\
\hline & {$[.0191]^{* * *}$} & {$[.0199]^{* * *}$} & {$[.0191]^{* * *}$} & {$[.0198]^{* * *}$} & & & \\
\hline \multirow[t]{2}{*}{ NDEATH $1995-2000$} & & & & & -3.4966 & -1.9335 & -2.1846 \\
\hline & & & & & {$[0.5731]^{* * *}$} & {$[.5213]^{* * *}$} & {$[.5200]^{* * *}$} \\
\hline $\mathrm{F}$ & 39.56 & 35.05 & 47.06 & 41.86 & 37.21 & 13.76 & 17.64 \\
\hline Observations & 12144 & 11869 & 12144 & 11869 & 11869 & 11869 & 11869 \\
\hline
\end{tabular}

Table 7 . Results of IV estimations. Robust standard errors in brackets. 


\begin{tabular}{|c|c|c|c|c|c|}
\hline & (1) & $(2)$ & $(3)$ & (4) & (5) \\
\hline Dep.Var & INN_PROC & INN_PROC & INN_PROD & LOG_TURN & LOG_OCC \\
\hline \multirow{2}{*}{$\mathrm{PERS}_{1985-2000} * \mathrm{D}_{A G E<15}$} & -.2092 & & .1362 & .3117 & .3570 \\
\hline & {$[.1287]$} & & {$[.1151]$} & {$[.1879]^{*}$} & {$[.2175]$} \\
\hline \multirow[t]{2}{*}{$\mathrm{PERS}_{1985-2000} * \mathrm{D}_{A G E>15}$} & -.2672 & & & & \\
\hline & {$[.1258]^{* *}$} & & & & \\
\hline \multirow{2}{*}{ PERS $_{1985-2000} * \mathrm{D}_{-}$PUBLIC } & & -.2906 & & & \\
\hline & & {$[.1298]^{* *}$} & & & \\
\hline \multirow[t]{2}{*}{$\mathrm{PERS}_{1985-2000} *\left(1-\mathrm{D} \_\mathrm{PUBLIC}\right)$} & & -.2366 & & & \\
\hline & & {$[.1246]^{*}$} & & & \\
\hline Wald Test & 0.16 & 0.12 & & & \\
\hline \multicolumn{6}{|l|}{ FIRST STAGE } \\
\hline \multirow[t]{2}{*}{ DEATH $_{1995-2000}$} & & & -.1823 & -.1842 & -.1815 \\
\hline & & & {$[.0219]^{* * *}$} & {$[.0219]^{* * *}$} & {$[.0225]^{* * *}$} \\
\hline Observations & 11550 & 11869 & 11869 & 11751 & 11869 \\
\hline
\end{tabular}

Table 8. Results of IV estimations for splitted sample and alternative dependent variables.

Robust standard errors in brackets. 


\subsection{Municipality-level variables}

ALTITUDE: altitude of the town hall, from ISTAT.

$C A P_{-} R E G$ : dummy for region capital, from ISTAT.

CAP_PROV: dummy for province capital, from ISTAT.

$C O M$ : full name of municipality, from ISTAT.

CSOUTH: dummy for Center, South and Islands.

$D_{-}$15: dummy for municipalities with population in 2001 above $15 \mathrm{~K}$.

$D_{-} P R$ : dummies for provinces.

$D_{-} R E G$ : dummies for regions.

$D E A T H_{1995-2000}$ : dummy indicating whether at least one politician aged 60 years or lower died during his/her appointment in the period between 1/1/1996 and 31/12/2000, from Italian Ministry of Internal Affairs (MI).

ELD_INDEX: elderly index (share of $65+$ inhabitants) from 2001 census, from ISTAT.

$L F P R$ : labor force participation rate from 2001 census, from ISTAT.

NDEATH $H_{1995-2000}$ : number of politicians aged 60 years or lower dead during their appointment in the period between $1 / 1 / 1996$ and $31 / 12 / 2000$, divided by the average number of politicians in place at any point in time, from MI.

$N_{-}$ISTAT: code of municipality from ISTAT classification (release date 31/03/09).

$N_{-} P R O V$ : code of province from ISTAT classification (107 provinces, classification of 2006).

PERS $S_{Y 1-Y 2}$ : average number of years spent within the local institutions in the period $Y 1-Y 2$ by politicians of each municipality, with $Y 1-Y 2=\{1985-2000,1985-$ 2007, $1995-2007\}$ ), from MI.

$P O P$ : population from 2001 census, from ISTAT.

SH_FOR: share of foreign residents from 2001 census, from ISTAT.

TERT_EDU: share of labor force with tertiary education at the Local System of Labor level in 2001, from ISTAT.

\subsection{Firm-level variables}

Source: Observatory over Small and Medium Enterprises, Capitalia, waves 8 and 9, and Unicredit, wave 10 .

$A G E$ : age of the firm.

COM: full name of municipality in which the firm is located, coded from ISTAT. 
D_EXPORT: dummy taking value of one if the firm declared to export a positive share of the production in the period covered by the survey (1998-2000, 2001-2003, and 2004-2006)

D_HITECH: dummy taking value one for the following industries: 24 - chemicals; 29 - non-electric machinery; 30 - office equipment and computers; 31 - electric machinery; 32 - electronic material, measuring and communication tools, TV and radio; 33 - medical apparels and instruments; 34 - vehicles; 35 - other transportation.

$D_{-} P U B L I C$ : dummy taking value one for the following industries: 21 - paper products; 22 - printing and publishing; 24 - chemicals; 25 - rubber and plastics; 28 - metal products; 29 - non-electric machinery; 33 - medical apparels and instruments; 35 - other transportation.

D_SECT: industry dummies (value one if the firm's main activity is within the industry, zero otherwise): 15 - food and beverages; 16 - tobacco; 17 - textiles; 18 - clothing; 19 - leather; 20 - wood; 21 - paper products; 22 - printing and publishing; 23 - oil refining; 24 - chemicals; 25 - rubber and plastics; 26 - non-metal minerals; 27 - metals; 28 - metal products; 29 - non-electric machinery; 30 - office equipment and computers; 31 - electric machinery; 32 - electronic material, measuring and communication tools, TV and radio; 33 - medical apparels and instruments; 34 - vehicles; 35 - other transportation; 36 - furniture; 37 - waste management and recycling.

D_WAVE: wave dummies (9, 8 and 10).

EXTERNAL: dummy taking value of one if the firm declared to use workforce from external work agencies in the period covered by the survey (1998-2000, 2001-2003, and 2004-2006).

GROUP: dummy taking value one if the firm declared to be part of a business group in the period covered by the survey (1998-2000, 2001-2003, and 2004-2006).

INN_PROC (INN_PROD): innovation dummy taking value 1 if the firm declared to have introduced at least one process (product) innovation in the period covered by the survey (1998-2000, 2001-2003, and 2004-2006), and zero otherwise.

MAIN_CONTR_PERS: dummy indicating whether the firm's main controller is a person.

$L O G_{-} T U R N$ : $\log$ of turnover in the first year of the survey.

$L O G_{-} O C C$ : $\log$ of number of workers in the last year of each survey.

$O C C_{-}$TOT: number of workers in the last year of the survey.

$S H_{-} O C C_{-} R D$ : share of workforce working in $\mathrm{R} \& \mathrm{D}$ activity in the last year of each survey. 
$S O C_{-} C A P$ : dummy taking value one if the firm declared to be a corporation in the period covered by the survey (1998-2000, 2001-2003, and 2004-2006).

TURNOVER: turnover in the first year of the survey. 


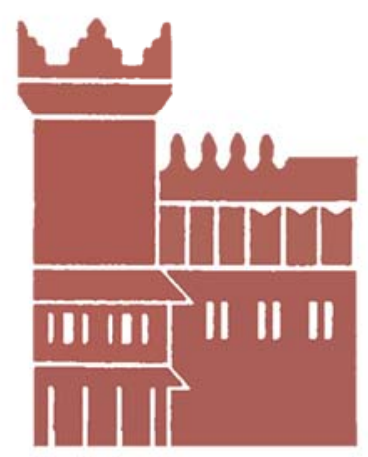

Alma Mater Studiorum - Università di Bologna DEPARTMENT OF ECONOMICS

Strada Maggiore 45

40125 Bologna - Italy

Tel. +39051 2092604

Fax +390512092664

http://www.dse.unibo.it 